\title{
胸鎖関節脱臼の治療経験
}

\author{
熊本整形外科病院 \\ 生 田拓 也・菊田朋朱 \\ 川嶌眞之
}

\section{Clinical Experience of Sternoclavicular Joint Dislocation}

\author{
Takuya Ikuta, Tomomi Kikuta, and Masayuki Kawashima \\ Kumamoto Orthopaedic Hospital
}

Three cases with sternoclavicular joint dislocation were treated.

They were classified into arterior dislocation ( 2 cases) and posterior dislocation (1 case).

In all cases, open reduction and internal fixation using two Kirschner wires with stopper was performed. In all cases, the disc was out of the joint, and was detached from the clavicle and sternum.

All cases recovered full ROM of the shoulder joint without pain and instability.

Key words : sternoclavicular joint dislocation（胸銷関節脱臼）, anterior（前方), posterior（後方）, treatment（治療）

はじめに

胸鎖関節脱巨比較的発生頻度の低い外傷である. 今回我々は本脱臼を 3 例経験し，いずれも手術治療を 行い良好な結果を得ているので報告する.

\section{症 例 の 概 要}

症例は 3 例である. 全例男性で受傷時年齢はそれぞ れ 73 歳, 45 歳, 34 歳であった. 受傷原因は転落 2 例, スポーツ外傷 1 例であり, 前方脱臼 2 例, 後方脱臼 1 例であった．前方脱臼の 1 例は鎖骨遠位端骨折を合併 していた．全例観血的に整復し内固定を行った．全例 抜釘術後の再脱臼もなく症状は軽快した。

\section{症例}

症例 2.45 歳, 男性, 前方脱臼.

自転車走行中, 転倒し約 $2 \mathrm{~m}$ の側溝に転落し受傷し た. 直後より右前胸部痛出現し当院を受診した. 初診
時, 胸鎖関節部に前方に突出する変形及び圧痛を認め た. 突出部は用手的に容易に整復されるも容易に再脱 臼し,いわゆる piano key sign を認めた。

単純X線前後像では鎖骨がやや上方に偏位し，肺尖 位像では前方に偏位していた．CTにても鎖骨の前上 方への転位を認めたが, 仰臥位にて撮影するためか転 位の程度汁軽度であった（図 1 )。

胸鎖関節前方脱臼の診断のもと, 鎖骨バンドにて保 存的治療を試みたが, 受傷後 2 週間経過しても肩関節 を水平屈曲させると容易に再脱臼するため, 手術治療 を行うこととした，術中，胸鎖関節部を展開すると関 節円板が遊離逸脱しており，これが容易に再脱臼する 原因かと考えられた．関節円板を摘出し関節部を整復 後, 径 2.0mmK-wire 2 本にて固定を行い葛岡ら ${ }^{5)}$ の 方法に準じて，K-wire の末端にループをつくり，A Omini screw をストッパーとして挿入固定した。さ らに周囲の軟部組織の修復を行った。

術後は 3 週間鎖骨バンド固定を行った，症状は徐々 


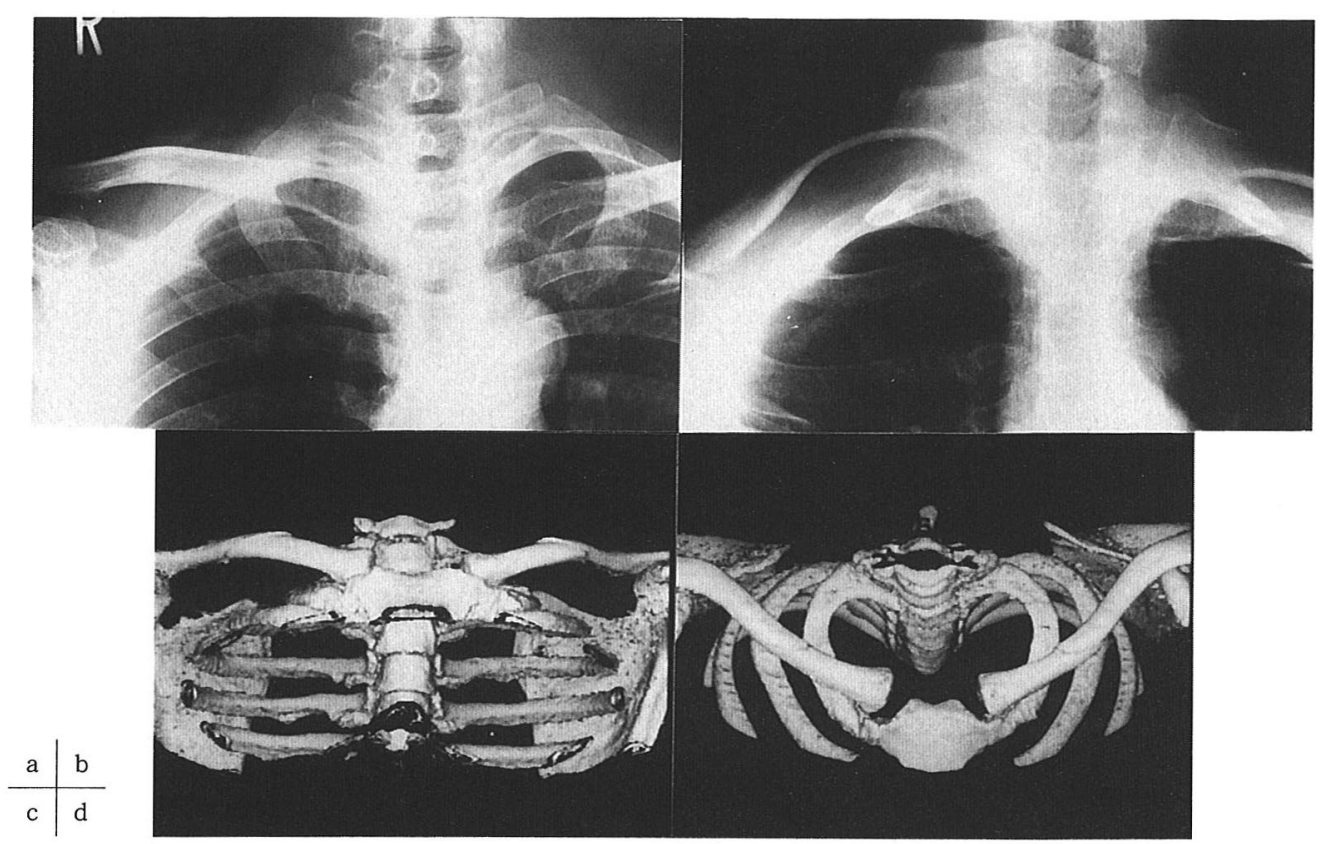

図 1 症例 2-1.45 歳, 男性, 前方脱臼

受傷時単純 X線前後像では鎖骨がやや上方に偏位し，肺尖位像では前方に偏位していた。
a . 受傷時前後像
b. 受傷時肺尖像
c. d. 3DCT 像

に俥快し術後 12 週で抜釷術を行った。術後 1 年 5 カ 月の現在，鎖骨近位部の軽度の突出は認めるものの piano key signはなく, 胸部痛や右肩の運動制限む なく原職の消防士の仕事に復帰している(図 2).

症例 3. 34 歳, 男性, 後方脱臼.

ラグビーの試合中にタックルされて受傷した（受傷 肢位は不明). 直後より前胸部痛あり当院を受診した. 初診時，胸鎖関節部に圧痛及び陌没を認めた。呼吸困 難ならびに大血管症状は認めなかった。

単純X線前後像, 肺尖位像及びCT にて明らかな胸 鎖関節後方脱臼を認めた（図 3 ).

受傷後 5 日目に手術を行った。術中，鎖骨前縁之胸 骨後縁間に関節円板が介存しており，これが整復阻害 因子となっていた，関節円板を摘出し，関節部を整復 後, 症例 2 と同様にストッパー付 K-wire 2 本にて固 定を行い，関節包勒帯等の軟部組織を修復し手術を終 了した.

術後は症例 2 と同様, 3 週間鎖骨バンド固定を行っ た. 症例は徐々に軽快し, 術後 10 週で抜釘術を行っ
た. 術後 8 カ月の現在, 胸部痛や右肩の運動制限もな く, 症状は軽快している(図4).

\section{考察}

1. 受傷機転について

胸鎖関節は鎖骨近位端と胸骨の鎖骨切痕および第 1 肋骨よりなり，関節円板で関節面が分離されており， 関節包, 勒帯などの軟部組織により安定性が保たれて いる ${ }^{3)}$.

受傷機転としては, 前方脱臼は, 介達外力が肩の上 方や前方加ら加わった時に第 1 肋骨を支点として起こ るとされる.一方, 後方脱臼は, 直達外力が鎖骨近位 端へ前方より加わった場合と, 介達外力が肩挙上, 前 方屈曲位にて後外側より加わった場合に起こるとされ ている2.

我々の症例は, いずれも前胸部の表在性には擦過傷 等の外傷はなく, 介達外力により生じたもの之推察さ れた。

2. 診断について 


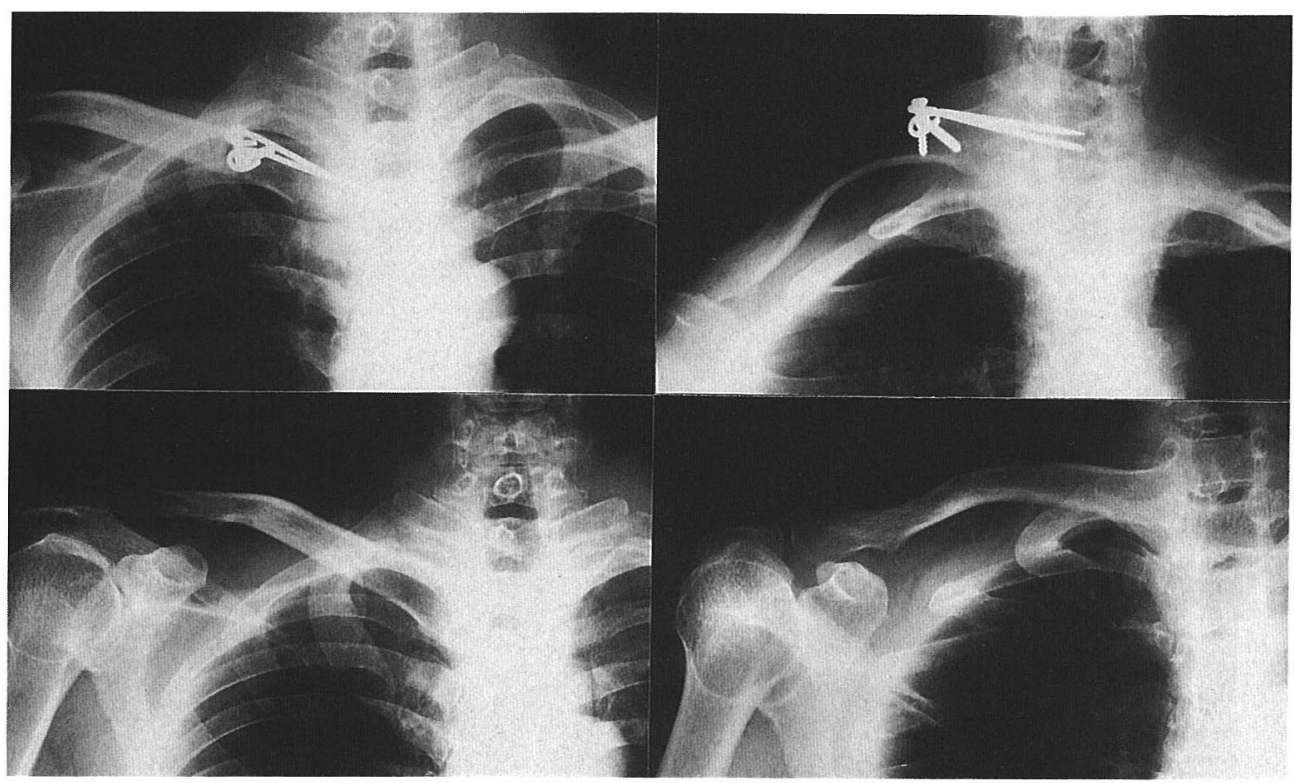

\begin{tabular}{l|l}
$\mathrm{a}$ & $\mathrm{b}$ \\
\hline $\mathrm{c}$ & $\mathrm{d}$
\end{tabular}

図 2 症例 $2-2$

K-wire の末端にループをつくり，A0mini screw をストッパーとして挿入固定した。 さら に周囲の軟部組織の修復を行った。

a. b. 術後
c. d. 抜釘術後

症状として, 胸銷関節部の膨張, 疼痛, 圧痛, 変形 および運動痛があり, 新鮮例であれば, 臨床的には, 診断は容易である。

単純 X線前後像のみでは判別が難しく, 肺尖位像に て転位がはっきりすることが多く有効である。また， CT は鎖骨の転位のみでなく, 縦隔への圧迫の程度も

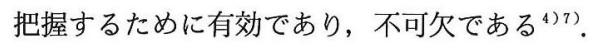

\section{3. 治療について}

前方脱臼の場合は保存的治療で良好な結果が得られ るとされている。 しかし我々の症例はいずれも容易に 再脱臼を起こすため手術を行った，術中の所見では関 節円板の逸脱が再脱臼の大きな要因であり, 保存的治 療では限界があったと考えられた。 また, 後方脱臼で は, 徒手整復不能例に手術の適応があるとされている. 我々の症例では徒手整復は不能であり, 手術を行った。 術中の所見では関節円板が鎖骨前縁と胸骨後縁間に介 存しており，これが徒手整復困難である大きな要因で あると考えられた，我々の症例に共通することは関節 円板が正常な胸鎖関節部に存在せずなおかつ鎖骨, 胸 骨のいずれとあ分離していたということである。この
様な状態では保存的な治療では整復位の保持のみなら ず整復さえも困難であると考えられた。

さて, 手術法であるが, 我々は最小限の侵襲で治療 を行うべきと考元, 勒帯再建や骨切りなどは行わず関 節包勒帯及び軟部組織の修復を行い K-wire 2 本にて 固定を行った. K-wireによる固定については破損例

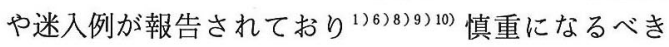
であるとの報告む多いが, K-wire を2 本用いること， 葛岡ら ${ }^{5)}$ の方法に準じたストッパーを併用することで 対処し良好な結果を得た。本法は胸鎖関節の固定法之 しては簡便で有用な方法であると考えられた。

\section{ま と め}

1. 前方 2 例, 後方 1 例, 計 3 例の胸鎖関節脱臼を 経験した。

2. 3 例とも手術治療を行い良好な結果を得た。

3. 整復阻害因子としては関節円板の介在が考えら れた.

4. 胸鎖関節の内固定法としてはストッパー付き K-wire が簡便で有効であった。 


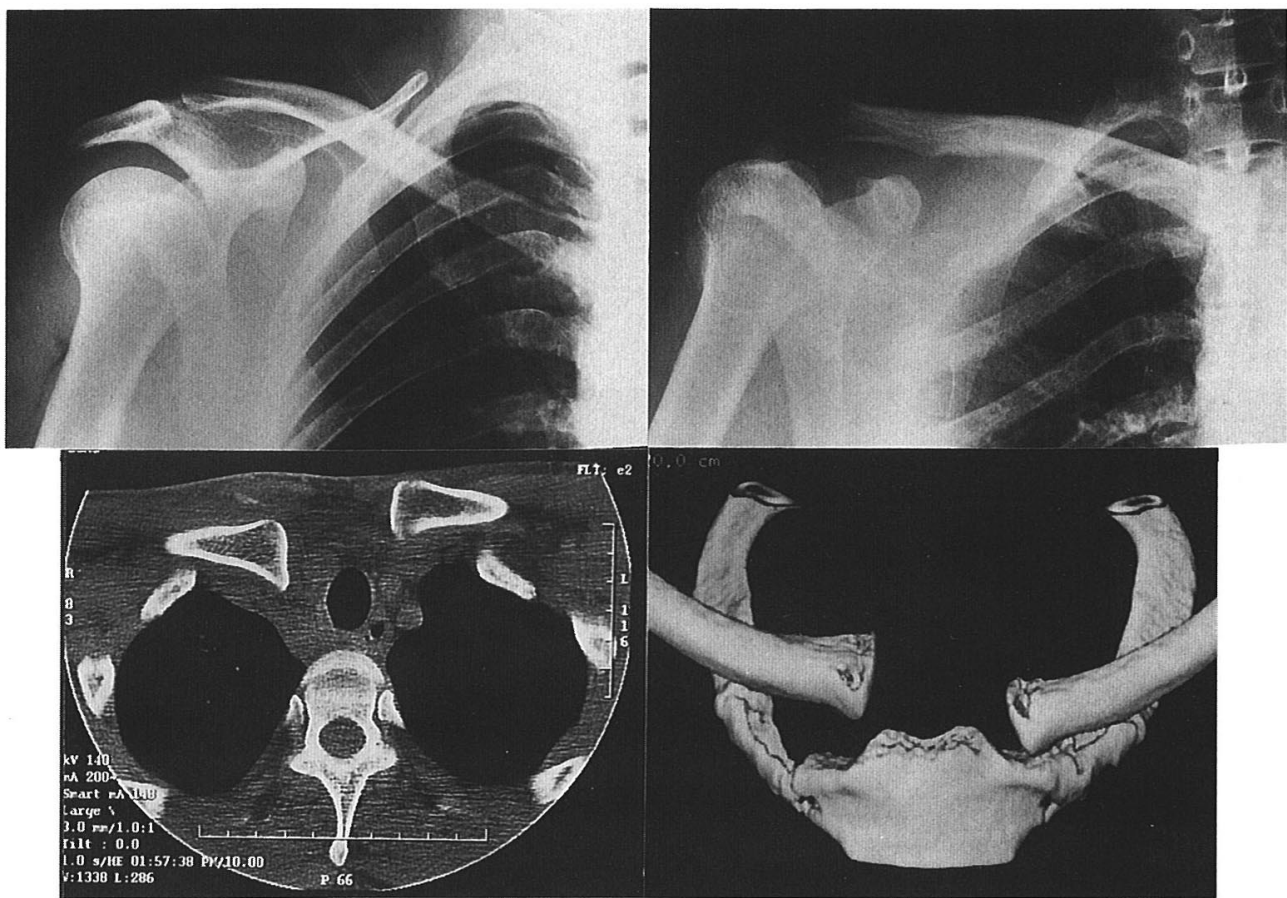

\begin{tabular}{l|l}
$\mathrm{a}$ & $\mathrm{b}$ \\
\hline $\mathrm{c}$ & $\mathrm{d}$
\end{tabular}

図 3 症例 3-1，34 歳, 男性, 後方脱臼

受傷時単純X線前後臓，肺尖位像及び CT にて明らかな胸鎖関節後方脱臼を認めた。 a. 受傷時前後像严受傷時肺尖像
c. CT 像
d. 3DCT 像

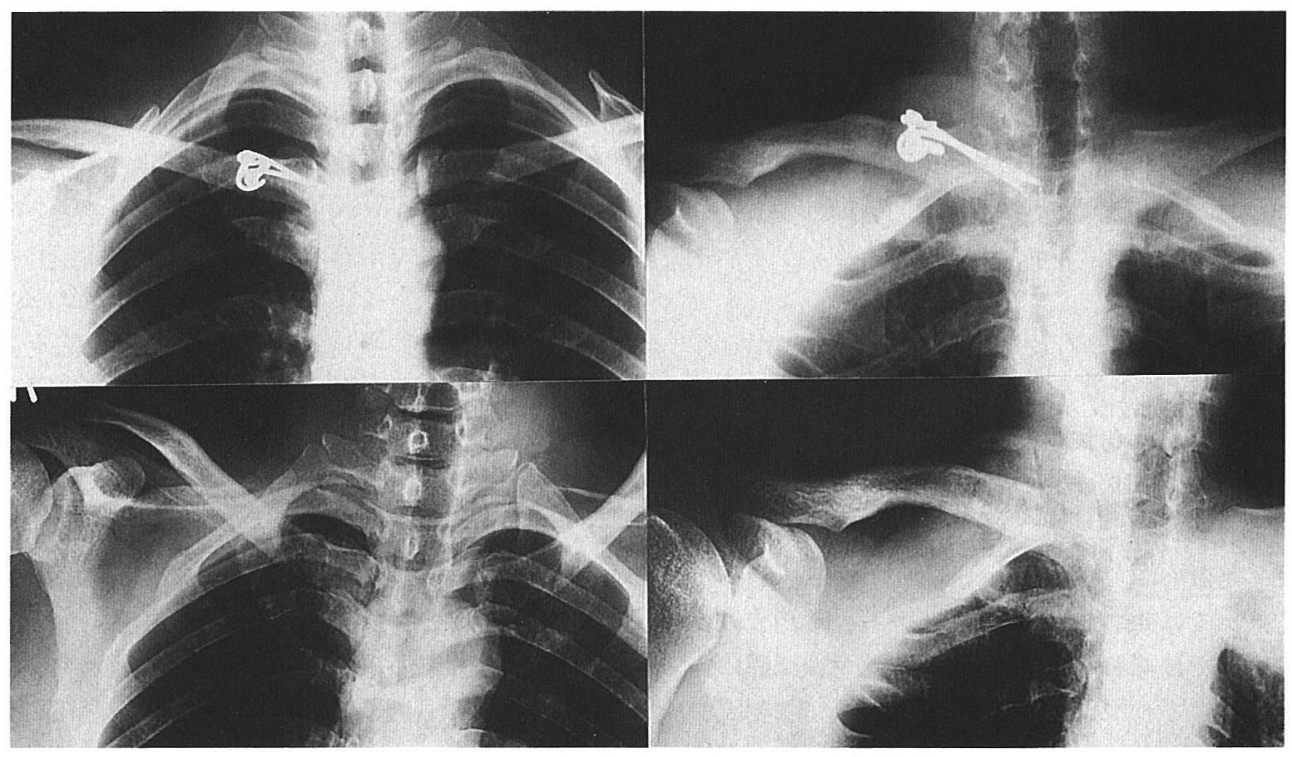

\begin{tabular}{l|l}
$a$ & $b$ \\
\hline$c$ & $d$
\end{tabular}

図 4 症例 3-2

症例 2 と同様にストッパー付 K-wire 2 本にて固定を行い，関節包勒帯等の軟部組織を修復した。 a. b. 術後 c. d. 抜釘術後 


\section{参 考 献}

1) Clark, R. L. et al. : Fatal aortic perforation and cardiac tamponade due to a Kirschner wire migration from the right sternoclavicular joint. South Med. J. 67 : 316-318, 19.74.

2) DePalma, A. F : Dislocations of the shoulder girdle. Surgery of the Shoulder (ed. by DePalma AF et al), 3rd ed, JB Lippincott, 428-460, 1983.

3）伊藤信之 : 胸鎖関節の機能と解剖. 関節外科, $10: 31$ 36, 1991 .

4）加藤雅典ほ加：外傷性胸鎖関節脱臼. 整形外科， 34 : 458-462, 1983

5）葛岡健作ほか：ストッパー付き Kirschner 鋼線による 鎖骨骨体部骨折の観血的治療. 整形外科, 49:105-109,
1998.

6) Leonard, J. W. et al. : Migration of a Kirschner wire from the clavicle into the pulmonary artery. Am. J. Cardiol. $16: 598-600,1965$.

7）丸山公ほか：胸銧関節脱臼の診断之保存的治療法 - Panclavicular dislocation を含む一. 関節外科, 10 : 37-40, 1991.

8）森本敬三ほか：神経血管症状を呈した胸鎖関節後方脱 臼の 1 治療例. 臨整外, $12: 84-87,1977$.

9) Pate, J. W. et al. : Migration of a foreign body from the sternoclavicular joint to the heart ; a case report. Am. Surg, 35 : 448-449, 1969.

10）坂田敏郎ほか：陳旧性胸銷関節脱臼一観血的整復を要 した 1 例一整形外科, $32: 626-630,1981$. 